\title{
The territorial dimension of "Europe 2020": Mapping European regions under the strategy to emerge from the crisis
}

\author{
Rubén Camilo Lois González, Valerià Paül, Juan-Manuel Trillo-Santamaría \\ Department of Geography, University of Santiago de Compostela, Galicia (Spain) \\ Email address: \\ rubencamilo.lois@usc.es (R. C. L. González),v.paul.carril@gmail.com (V. Paül), \\ juanmanuel.trillo@usc.es (Juan-Manuel Trillo-Santamaría)
}

\section{To cite this article:}

Rubén Camilo Lois González, Valerià Paül, Juan-Manuel Trillo-Santamaría. The Territorial Dimension of "Europe 2020": Mapping European Regions under the Strategy to Emerge from the Crisis. Social Sciences. Special Issue: Geographical evidence in changing Europe. Vol. 3, No. 4-1, 2014, pp. 13-27. doi: 10.11648/j.ss.s.2014030401.13

\begin{abstract}
The Europe 2020 Strategy (EU2020S) was launched by the European Commission (EC) in November 2009. The consolidated official document of the EU2020S constitutes a Communication from the Commission published in March 2010, being finally adopted by the European Council on the 17th of June 2010 in a meeting held in Brussels. The EU2020S has as meaningful subtitle: "a strategy for smart, sustainable and inclusive growth". That is to say, the EU2020S, first and foremost, seeks growth and considers that this prime objective must be achieved through three priorities, also known as pillars. If the strategic document of the EU for the decade 2000-2010 was the so-called Lisbon Strategy, the intended strategic document for the decade 2010-2020 is the EU2020S. Mainly, the need of a new strategic direction of the EU is motivated by the crisis context. The EU2020S contains eight headline targets that are set for being achieved by 2020. In short, the EU2020S indicates the basic direction that the EU economy should follow and this direction is intended to be measurable by means of some indicators, that is, the headline targets. For the purpose of the SIESTA Project, devoted to grasp the regional dimension of the EU2020S, all these objectives have been considered to be indicators to be mapped, mainly at NUTS 2 level. This way, the project seeks overcoming what some specialists have called the "territorially blind" dimension of the EU2020S. This paper presents the main results of the SIESTA Project by showing the maps directly related with the targets which the EU2020S issues to measure its fulfilment. Additionally, in order to assess the overall fulfilment of the EU2020S, a composite index has also been developed. It measures the distance of regions from the eight EU2020S headline targets: a region would score 100 if it had reached all eight targets, while a region furthest away from all eight targets would score 0 . This methodology was inspired by the Lisbon index of the 5th Cohesion Report.
\end{abstract}

Keywords: EU2020S, Regions, SIESTA Project

\section{Introduction}

The Europe 2020 Strategy (EU2020S) was issued in 2010 by the European Commission (EC). It basically constitutes a growth scheme for the decade 2010-2020 and aims to help the European Union (EU) recover from the current ongoing crisis through the so-called smart, sustainable and inclusive dimensions of growth. Due to this strategy's great importance - which leaves its imprint on all the European policies of the current decade - ESPON (European Observation Network for Territorial Development and Cohesion) announced in early 2011 a call for applications for the development of a research project to "territorialize" this document. This is consistent with one of the expectations of the EU2020S itself, which clearly states that "the benefits of economic growth spread to all parts of the EU, including its outermost regions, thus strengthening territorial cohesion" (European Commission, 2010a: 16). However, it has to be pointed out that the territorial dimension of the EU2020S is not something obvious. Scholars such as Böhme et al. (2011: 25) have stated that the EU2020S is "territorially blind," thus making this research project particularly challenging.

This article presents the main results of the project which won the call for applications, under the leadership of the 
University of Santiago de Compostela. ${ }^{1}$ The methodology employed consisted mainly of mapping the variables that the EU2020S uses for measuring its implementation. With the EU2020S laying down the path out of the crisis, this project allows us to find out the current position of each of the territorial units studied. The project has not taken into consideration the suitability of the EU2020S itself; instead, it has aimed its efforts into determining how the territories are doing in relation to the strategy's goals. Thus, the objective has not been so much evaluating the EU2020S, but inferring its territorial dimension. We therefore hypothesize that territories not complying with the EU2020S are far from overcoming the crisis, or are more seriously affected by it. This article includes only those maps directly related with the targets which the strategy issues to measure its fulfillment (Lois and Paül, 2013; ESPON, 2013).

Maps in this paper represent the regions of the countries participating in the ESPON Program, which consists of the twenty-seven EU member states, plus Iceland, Liechtenstein, Norway and Switzerland. In addition, the intention of the SIESTA Project regarding Croatia (acceding country to the EU while SIESTA was in process), EU candidate countries (Macedonia, Montenegro, Serbia and Turkey), and other Western Balkan countries (Albania, Bosnia and Herzegovina, and Kosovo), was to fully integrate them into the analysis at a regional scale through their consistent consideration in terms of indicators and maps; however, the lack of data for many of the indicators selected has compromised this purpose. In any case, the SIESTA Project systematically tried to develop the work at a larger scale, that is, NUTS3 regions and urban areas, but only when this was possible in terms of data availability. This means that, when data was not available for NUTS3, the NUTS2 regions were used and, in some exceptional cases and always depending on data availability, NUTS1 or NUTS0 (entire countries). ${ }^{2}$ For this reason, maps are mainly at NUTS2 level and cover the wider possible area of the European space.

The article is organized into six sections. Section (i) is the introduction. Section (ii) analyzes the EU2020S and reviews its main points. Afterward, we present three thematic sections which correspond with the priorities established by the EU2020S itself: (iii) smart growth, (iv) sustainable growth, (v) inclusive growth. These three central sections

\footnotetext{
${ }^{1}$ The name of the project is SIESTA, an acronym for "Spatial Indicators for a 'Europe 2020 Strategy' Territorial Analysis", financed by ESPON (Code 2013/1/18), developed between June 2011 and April 2013, by a consortium of eight institutions from seven European countries. The Project Coordinator is Rubén C. Lois González. The Project Manager is Valerià Paül. For complete information on the project, see: $<$ http://www.espon.eu/main/Menu_Projects/Menu_AppliedResearch/siesta.htm $1>$ (Accessed November 30, 2013). The project had seven more partners: Mediterranean University of Reggio-Calabria (Italy), Open Hellenic University of Greece, University of Bucharest, University College of Dublin, University of Poznan (Poland), the French CNRS in Paris I-La Sorbonne, and M-CRIT Consultants of Barcelona.

2 For a systematic consideration of NUTS terminology, see: http://epp.eurostat.ec.europa.eu/portal/page/portal/nuts_nomenclature/introducti on (Accessed December 5, 2013).
}

are basically composed of an analysis of the cartography generated by the project. Section (vi) presents an aggregated index showing a joint interpretation of the current position of the European regions in relation to the EU2020S. Finally, section (vii) critically evaluates the role of the EU2020S for overcoming the crisis of the EU regions.

\section{The EU2020S}

The EU2020S was launched by the EC in November 2009 and discussed in the first semester of 2010 by different EU institutions (the Parliament, the Council, etc.), with a first overall discussion held in the European Council meeting held on March 25-26, 2010, in Brussels. The consolidated official document of the EU2020S constitutes a Communication from the Commission published in March 2010 (European Commission, 2010a), being finally adopted by the European Council on June 17, 2010, in a meeting held in Brussels. The presidency of the EU at the time of the first semester in 2010 wanted the EU2020S to be binding for member states, ${ }^{3}$ an intention that would never materialize. Thus, the EU2020S is a document of a strategic nature; in other words, it is neither normative nor binding (Zoido et al., 2013).

The EU2020S has as meaningful subtitle "a strategy for smart, sustainable and inclusive growth." It seeks, first and foremost, growth and considers that this prime objective must be achieved through three priorities, also known as pillars, which, as the terms used in the subheading state, go beyond the strictly economic sense and embrace social and environmental questions. The document contains a preface of the President of the EC stating that the context of "economic and financial crisis" has motivated the elaboration of this EU2020S for achieving "a sustainable future", which is "about more jobs and better lives", acknowledging that the EU "has the capability to deliver smart, sustainable and inclusive growth, to find the path to create more jobs and to offer a sense of direction to our societies" (European Commission, 2010a: 2). This constitutes the basic rationale of the EU2020S.

If the strategic document of the EU for the decade 2000-2010 was the so-called Lisbon Strategy (also known as the "Lisbon Agenda" or "Lisbon Process"), the intended strategic document for the decade 2010-2020 is the EU2020S. The need of a new strategic direction of the EU is mainly motivated by the crisis context. According to the EU2020S, the global situation since $2008^{4}$ "has wiped out years of economic and social progress and exposed structural weaknesses in Europe's economy" (European Commission, 2010a: 4). Furthermore, there is ample agreement that the objectives set by the Lisbon Strategy have not been fulfilled

\footnotetext{
${ }^{3}$ Isenson, N. (2010). "Spain Calls for Binding EU Economic Goals - and Penalties." Deutsche Welle, August 1, 2010. $<\mathrm{http}$ //www.dw.de/spain-calls-for-binding-eu-economic-goals-and-penalties/a5098907-1> (Accessed January 13, 2013).

${ }^{4}$ According to Kotz (2009: 1), the year the global crisis started in the United States cannot be specified, but the majority of European countries certainly found themselves involved between 2007 and 2009.
} 
(for instance, Butković and Samardžija, 2010; Moltó, 2012; Lundvall and Lorenz, 2011).

The EU2020S consists of a double-folder of thematic organization (Figure 1): on the one hand, three priorities are launched; on the other, seven flagships are established. In relation to the priorities (also called pillars), they can be defined as the basic objectives that the EU2020S will attempt to attain by means of (in an inter-related manner):

- Smart Growth: developing an economy based on knowledge and innovation.

- Sustainable Growth: promoting a more resource efficient, greener and more competitive economy.

- Inclusive Growth: fostering a high-employment economy delivering social and territorial cohesion.

These three themes are understood to be the very basic framework of the EU2020S. Its denomination is reminiscent of the classic model of sustainability distributed in three large blocks (economic, environmental and social), popularized by the Rio de Janeiro Earth Summit in 1992, and frequently represented by a Venn diagram. The EU2020S apparently embraces the major issues that are globally considered to warrant attention through the paradigm of sustainability (Blewitt, 2008). Furthermore, it can be said that the EU2020S goes thematically beyond the previous Lisbon Strategy, as the latter was basically focused on economic and smart growth (competitiveness and knowledge-based economy) and included several social issues (basically employment).

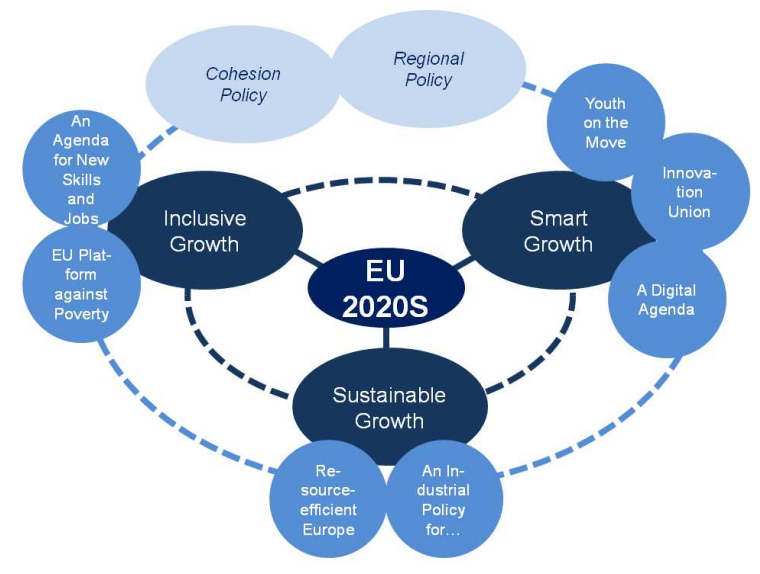

Figure 1. The EU2020S from the perspective of the SIESTA Project.

It is important to note from the outset, however, that the mention of sustainability in the EU2020S has little to do with the general understanding of this concept. Indeed, the sustainable growth proposed by the EU2020S must be understood in a macro-economic sense: basically, that growth must "hold up" in time and, therefore, degrowth — in which ample sectors of the EU have been immersed over the last five years - should be avoided. As stressed by Warleigh-Lack (2010: 307), "the language used in Europe 2020 _ 'sustainable growth' rather than 'sustainable development' — is not accidental. The former term does nothing to replace the idea that growth must be central to economic policy or to speak of the need for intergenerational solidarity. Responding to climate change is an afterthought, not the focus." At this point, Anton and Gonzàlez Reverté (2005: 49) are relevant when affirming that "authentic contradiction is only given in the meaning of sustainable growth, based on the philosophy of continuous growth, while the concept of sustainable development is considered more suitable." Naredo (2007) has summarized it in the axiom "unsustainable growth, sustainable development," which in practice denotes an inherent contradiction in the notion of sustainable growth.

In order to catalyze progress towards each one of the priorities, seven flagship initiatives are put forward. These are key programs or tools to foster the achievement of the EU2020S. These initiatives represent change inasmuch as they were absent in the development of the Lisbon Strategy. Legally, these have been resolved one by one through successive official communications in 2010, except for one which was approved the following year (European Commission, 2011a). The seven flagships are presented in Table 1.

Table 1. Flagships and Objectives of the EU2020S.

\begin{tabular}{|c|c|}
\hline Flagship & Objective \\
\hline $\begin{array}{l}\text { Innovation } \\
\text { Union }\end{array}$ & $\begin{array}{l}\text { To improve framework conditions and access to } \\
\text { finance for research and innovation to ensure } \\
\text { innovative ideas can be turned into products and } \\
\text { services. }\end{array}$ \\
\hline $\begin{array}{l}\text { Youth on the } \\
\text { move }\end{array}$ & $\begin{array}{l}\text { To enhance the performance of education systems and } \\
\text { to facilitate the entry of young people into the labor } \\
\text { market. }\end{array}$ \\
\hline $\begin{array}{l}\text { A digital } \\
\text { agenda for } \\
\text { Europe }\end{array}$ & $\begin{array}{l}\text { To speed up the roll-out of high-speed internet and } \\
\text { reap the benefits of a digital single market. }\end{array}$ \\
\hline $\begin{array}{l}\text { Resource } \\
\text { efficient } \\
\text { Europe }\end{array}$ & $\begin{array}{l}\text { To help decouple economic growth from the use of } \\
\text { resources, support the shift towards a low carbon } \\
\text { economy, increase the use of renewable energy } \\
\text { sources, modernize the transport sector, and promote } \\
\text { energy efficiency. }\end{array}$ \\
\hline $\begin{array}{l}\text { An industrial } \\
\text { policy for the } \\
\text { globalization } \\
\text { era }\end{array}$ & $\begin{array}{l}\text { To improve the business environment, and to support } \\
\text { the development of a strong industrial base able to } \\
\text { compete globally. }\end{array}$ \\
\hline $\begin{array}{l}\text { An agenda for } \\
\text { new skills and } \\
\text { jobs }\end{array}$ & $\begin{array}{l}\text { To modernize labor markets and empower people by } \\
\text { developing their skills throughout their lifecycle with } \\
\text { a view to increase labor participation and better match } \\
\text { labor supply and demand, including labor mobility. }\end{array}$ \\
\hline $\begin{array}{l}\text { European } \\
\text { platform } \\
\text { against } \\
\text { poverty }\end{array}$ & $\begin{array}{l}\text { To ensure social and territorial cohesion so the } \\
\text { benefits of growth and jobs can be widely shared, and } \\
\text { people experiencing poverty and social exclusion can } \\
\text { live in dignity and take an active part in society. }\end{array}$ \\
\hline
\end{tabular}

In terms of our research, regional and cohesion policies have also been included in Figure 1, despite not being expressly cited in the original EU2020S document. This is due to the fact that the Commission itself has adopted two communications - on the same level as the seven already mentioned - in which the achievement of the EU2020S objectives is sought through regional and cohesion policies; specifically related to smart growth (European Commission, 2010b) and sustainable growth (2011b). Also, the connection between regional and cohesion policies on the one hand, and the EU2020S on the other, has to do with the fact that the latest reports on territorial cohesion drawn up by 
Commission - the fifth in the triennial series (European Commission, 2010c), and seventh in a series evaluating the situation that is drafted every two years (European Commission, 2011c) — have also adopted the EU2020S as a reference for application at a regional scale (Colomb and Santinha, 2012). In addition, the Territorial Agenda of the European Union, initially adopted in 2007, was readapted in 2011 to comply with the EU2020S as well. ${ }^{5}$

Beyond priorities and flagship initiatives, the EU2020S consists of headline targets to be achieved by 2020 . In short, the EU2020S indicates the basic direction that the EU economy should follow, and this direction is intended to be measurable by means of certain indicators, that is, the headline targets. These targets are supposed to be inter-related. The official list of the EU2020S headlines is as follows:

- $\quad 75 \%$ of the $20-64$ year-old population to be employed.

- $\quad 3 \%$ of the EU's Gross Domestic Product to be invested in R\&D.

- The three targets known as "20/20/20": a 20\% reduction (and even 30\% if possible) in greenhouse gas emissions in relation to 1990 levels; $20 \%$ of energy from renewable sources; and a $20 \%$ increase in energy efficiency.

- $\quad$ Reducing early school leavers to below $10 \%$.

- At least $40 \%$ of $30-34$ year-old population completing third level education.

- $\quad$ At least 20 million fewer people in or at-risk-of-poverty and social exclusion.

All these objectives have been considered as indicators to be mapped in this article. The accomplishment of these targets is quite a controversial matter. Not only at member state level, where each country is establishing its own national headline target by adapting the general orientations of the EU, but also in the sense that each individual region is able to (or, at least, it would make sense that it do so) achieve the national or the EU headline targets. This is not stated in the EU2020S document itself. In late 2011, however, the Commission, by means of the Seventh Progress Report on Cohesion (European Commission, 2011c), acknowledged that it is not implicit that all the regions can or should reach the 2020 targets, recognizing that for some regions the distance to the target is simply too great. The Commission has also stated that for some issues it is not realistic or desirable that all regions reach the same target (European Commission, 2011c). The rationale for accepting that each country set its own national target derived from the EU target is in the EU2020S itself when it acknowledges that each country must take into account its different needs, different starting points and specificities so as to promote growth for all. However, the national targets are sometimes very heterogeneous and their sum country per country does not guarantee the achievement of the overall EU targets.

The EU2020S is assessed each year through progress reports on the fulfillment of the EU2020S for the whole of the EU and for member states. These reports are officially

\footnotetext{
${ }^{5}$ Although there are studies criticising the incoherence between the Territorial Agenda and the EU2020S (Böhme et al., 2011).
}

called the Annual Growth Survey (to date, there are reports available for 2011, 2012, 2013 and 2014). These reports link with the tradition started with the Lisbon Strategy in annually assessing the progress made by each country incidentally, with little luck (Çolak and Ege, 2013; Moltó, 2012; Treidler, 2011). Strikingly, the successive versions of the Annual Growth Survey seem to release contents directly related to the EU2020S. Surprisingly, in the 2013 and 2014 versions, the progress report on the EU2020S implementation has ceased, although it had appeared in the two previous years.

\section{Smart Growth}

The EU2020S underlines the essential role of research and development (R\&D), boosting job creation and economic growth. R\&D is the creative work undertaken on a systematic basis in order to increase the stock of knowledge and the use of this stock to devise new applications. The common indicator used is the percentage of GDP spent on R\&D, commonly known by its acronym, GERD (General Expenditure on R\&D). This indicator basically shows the resources devoted to $\mathrm{R} \& \mathrm{D}$ by a particular territory.

Map 1 shows the spatial disparity of GERD, represented in relation to the EU target, for the purpose of measuring internal variations. First, it has to be said that only 37 out of the 272 regions studied meet the $3 \%$ target; thus casting a shadow of doubt on the target as a whole being achieved by 2020 , even more so if the current contraction context is considered. In addition, it is not reasonable to expect that the target be achieved everywhere in Europe, as this will be impossible in a large number of regions which are poorly endowed and predictably will not be able to increase expenses in the following years. On the other hand, the generalized goal of $3 \%$ is not considered to be desirable by authors such as Capello (2012: 9), because R\&D has an accumulative effect and there is no sense in waiting for all regions to equally achieve the same critical mass.

In general, the regions surpassing the target are located in Germany, Belgium, Sweden, Finland, the UK, Austria, France and Denmark. Some scholars have stated that three main corridors can be distinguished in Europe (Bundesamt für Bauwesen und Raumordnung, 2006), which arguably might be seen on this map if all the regions above the $2 \%$ threshold are considered: Midi-Pyrénées to Bavaria, Styria to England, and Denmark to Finland; they constitute transnational corridors which cross several internal borders, and this is noteworthy in terms of economies of agglomeration and cooperation. Most of these regions are urban, while not necessarily being first-ranked metropolitan areas or capitals. For instance, in Spain not only Madrid ranks high, but also the Basque Country and Navarra. However, circumstances are quite particular, for example: Midi-Pyrénées (i.e. the concentration of a specific manufacturing sector, aerospace and aviation), or Styria (where low spin-off levels are recorded and, indeed, this region is to be found under the Austrian average in GDP per capita). 


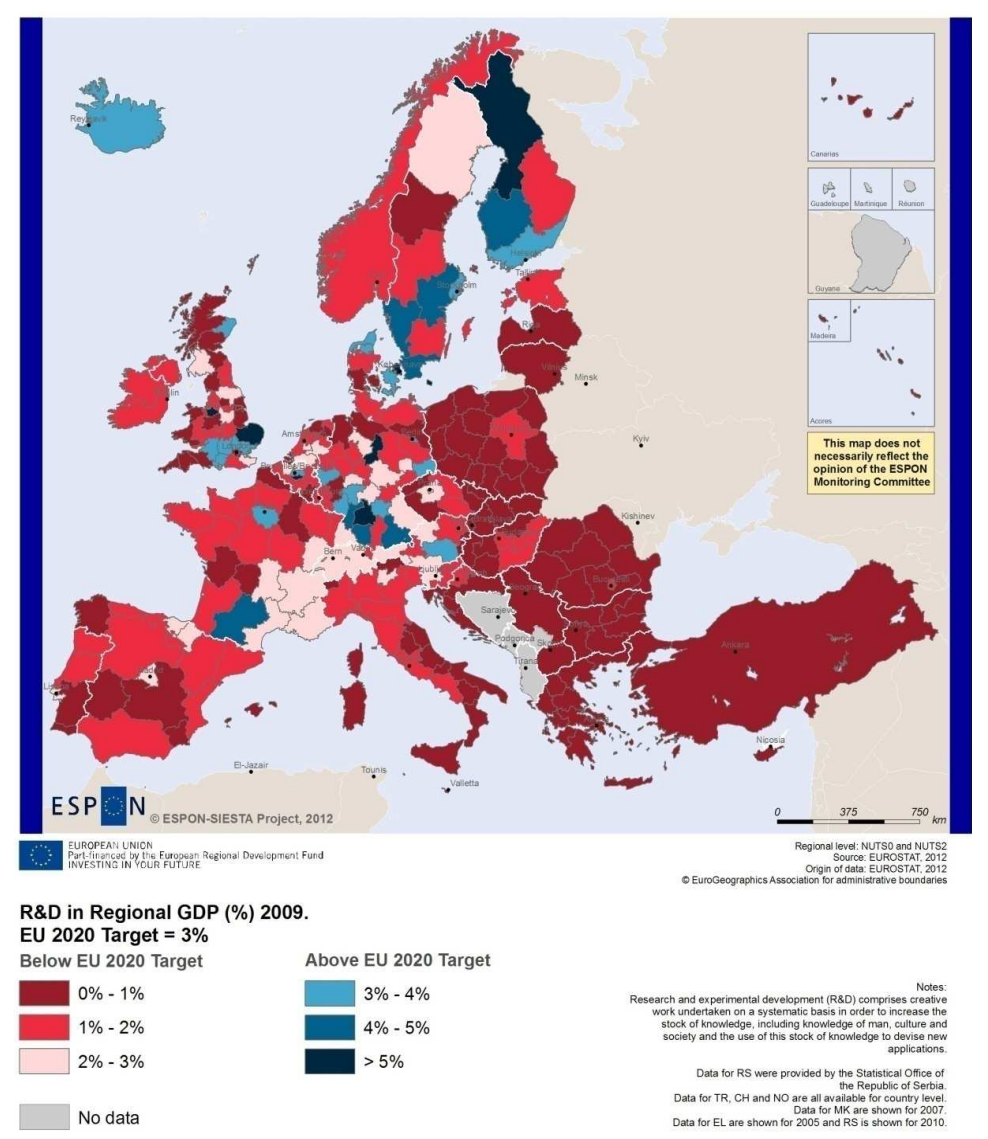

Map 1. GERD as percentage of regional GDP (2009).

In any case, the majority of the regions studied do not achieve the 3\% target. Regions especially lagging behind are mainly located in Eastern Europe and in southern parts of Italy, Portugal and Spain. Other individual regions show particularly dire scores: Galicia, the Scottish Highlands, etc. Some areas invest less than 0.5 of GDP in R\&D, especially in Bulgaria, Poland and Romania, extending to non-EU regions. Although it is unlikely that all of them reach $3 \%$, those regions ranking so poorly should be especially targeted. Research is important for all regions, whether they are currently leaders or not.

In terms of education, the EU2020S is very explicit in stating that "A quarter of all pupils have poor reading competences, one in seven young people leave education and training too early. Around 50\% reach medium qualifications level but this often fails to match labor market needs. Less than one person in three aged 25-34 has a university degree compared to $40 \%$ in the US and over $50 \%$ in Japan. According to the Shanghai Index, only two European universities are in the world's top 20" (European Commission, 2010a: 12). The assumption derived from these statements is that the EU education system as a whole has major weaknesses requiring improvement. The problems seem to be present at all educational levels, but the EU2020S measures education mainly through two indicators, as will be seen below.

The headline target that has been set for compulsory levels of education is to reduce the number of early school leavers (measured as a percentage of the population aged 18 to 24 ) to less than $10 \%$. It is worth mentioning that this was already a Lisbon target in 2000. The fact that a decade later it is clearly repeated indicates that it has not yet been achieved: the EU still has a figure of $15 \%$. In contrast to most of the maps presented in this contribution, the pattern in this case "favors" some Eastern European countries, for instance, Croatia, Slovakia, Poland and the Czech Republic (Map 2). However, some Eastern countries such as Romania and Bulgaria do not score particularly well. In addition, some regions of Western Europe are doing well, e.g., regions of Austria, Switzerland, Luxembourg and Belgium. Most of the regions that do not reach the target in countries such as Germany, France, the UK, Ireland, the Benelux countries, Scandinavia and the Baltic Sea Region are quite close to achieving it. This means that if a policy action is implemented and has success, regional rates would improve.

Map 2 also shows the particularly worrying situation of specific areas of Europe: four regions in Southern Spain (plus Ceuta, Melilla, Balearic and Canary Islands), four regions in Portugal (Azores, Madeira, Norte and Algarve), and Malta present very high drop-out rates (above 30\%). Outermost regions score particularly low. The regions that right now have a very bad score are not likely to meet the target, given that - while improvements can be made - the pace at which this occurs is slow, and 2020 is six years away. 
Indeed, it can be said that the fact that one third of the examined regions are very far from the target, compromises Europe's ability to emerge from the recession: it is impossible to have a smart economy when more than $45 \%$ of children do not obtain a secondary education (as in the case of the Azores or Ceuta, for instance), resulting in an unskilled future workforce which will not be able to work in knowledge-based jobs.

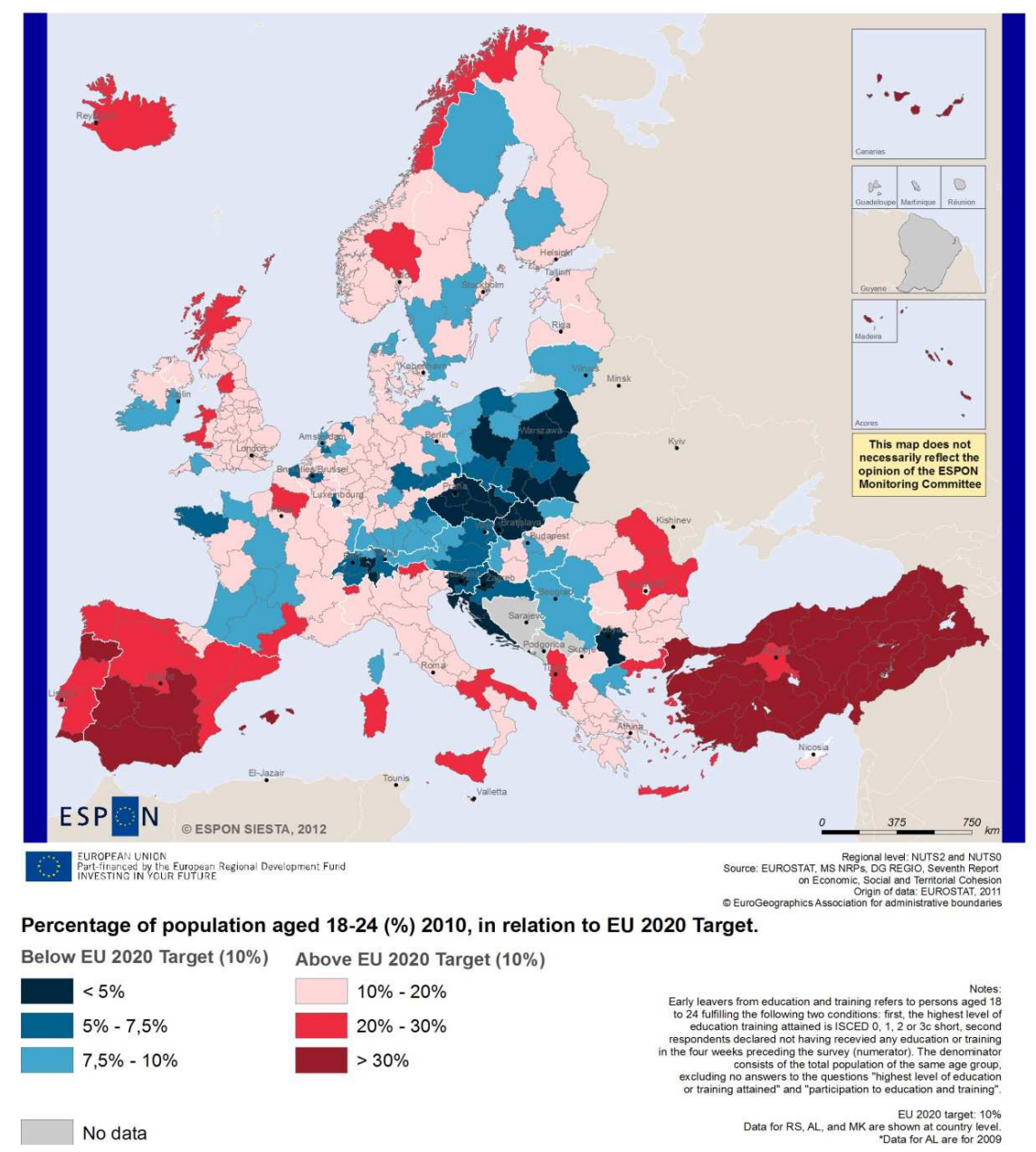

Map 2. Regional early school leavers from education and training as percentage of population aged 18 to 28 (school drop-out rates), (2010).

The EU2020S is concerned with the lower percentage of people having completed tertiary education. The EU sets the $40 \%$ official headline target based on the estimate that by 2020 , $35 \%$ of all jobs will require high-level qualifications. The average rate in 2010 for the whole EU is $33.6 \%$, making the overall target ambitious for the 2010-2020 decade. However, it is important to note that this average masks a much more complex reality and a very uneven European geography (Map 3). In general, Northern Periphery countries, North-West regions and France and Spain score particularly well, above the EU target or thereabouts. Surprisingly, outperforming economies such as Germany or Austria and a typically Western country like Italy score very low, and their regions are generally quite far from the EU target; in the case of Germany and Austria this might be due to its educational system: non-comparable levels of post-secondary education and non-university tertiary education which are of a polytechnic nature that possibly have not been accounted for.

The map shows how urban and metropolitan regions tend to score better than rural regions. Typically, a great number of university graduates remain in the region where they have studied due to professional opportunities; this is the situation of capitals (London, Copenhagen, Oslo, Stockholm, Brussels, Paris, Madrid, Dublin, etc.), which in addition attract tertiary educated people from elsewhere. This is also the case of regions such as the Basque Country and Navarra, Utrecht, Scotland and Northern Scandinavia, where regional universities and adequate job opportunities play a crucial role. It is important to mention that some high-scoring regions are being affected by the crisis (for instance, Northern Spain and Ireland); in these cases, predictably, there will be a 'brain drain' (indeed, it is currently occurring) to areas where there are job opportunities commensurate to their educational levels. 


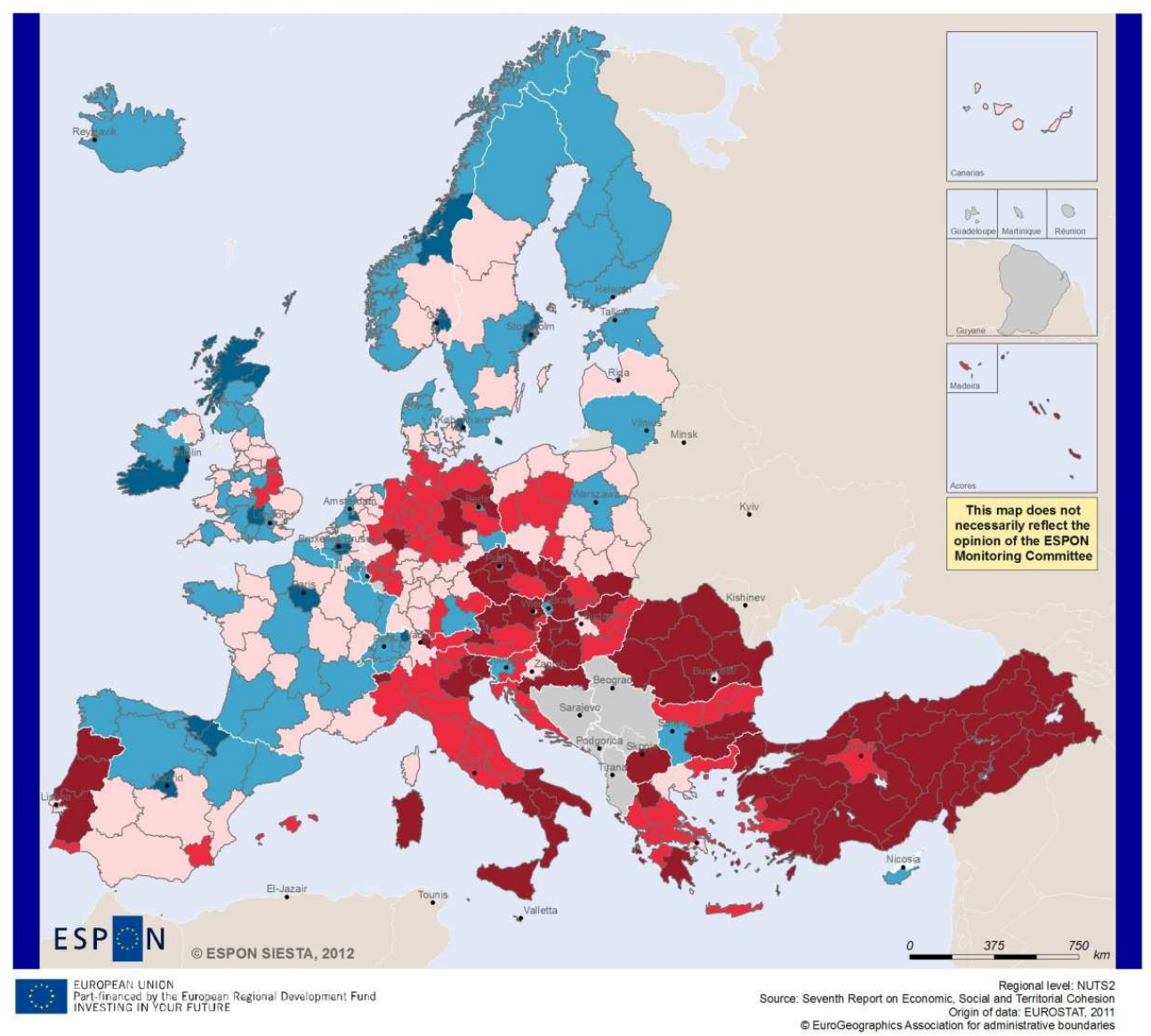

Percentage of total population aged 30-34 (\%) 2010. EU 2020 Target $=40 \%$

\begin{tabular}{ll} 
Below EU 2020 Target & Above EU 2020 Target \\
$<20 \%$ & $40 \%-50 \%$ \\
$20 \%-30 \%$ & $>50 \%$ \\
$30 \%-40 \%$ & \\
\hline No data & \\
\hline
\end{tabular}

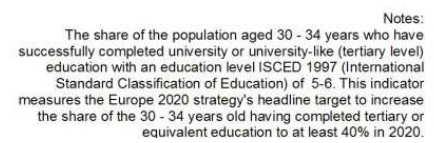

Map 3. Regional population aged 30 to 34 with tertiary education (2010).

\section{Sustainable Growth}

Sustainable growth in the sense given by the EU2020S primarily envisages a European economy which maintains its leadership in the world and its competitiveness, especially through the delivery of new processes and technologies. The documentation states that this economy might be especially focused on green technologies which reduce climate change (by means of low-carbon technologies), tending to achieve energy efficiency. The EU2020S acknowledges that such an approach will prevent environmental degradation, biodiversity loss and unsustainable use of resources. In addition, it is evident that resource efficiency is important for businesses, the public and governments, has obvious security and geopolitical implications (i.e., the need to reduce dependency on non-EU countries), and has the potential for creating jobs in this sector. For all these reasons, there is a correlation between resource efficiency and economic competitiveness.

One of the headline targets of the EU2020S is for the development of renewable sources, particularly regarding the share of renewable energy in gross final energy consumption, which should reach $20 \%$ in 2020 . Map 4 shows the current ratio in terms of the desired 2020 objective. 

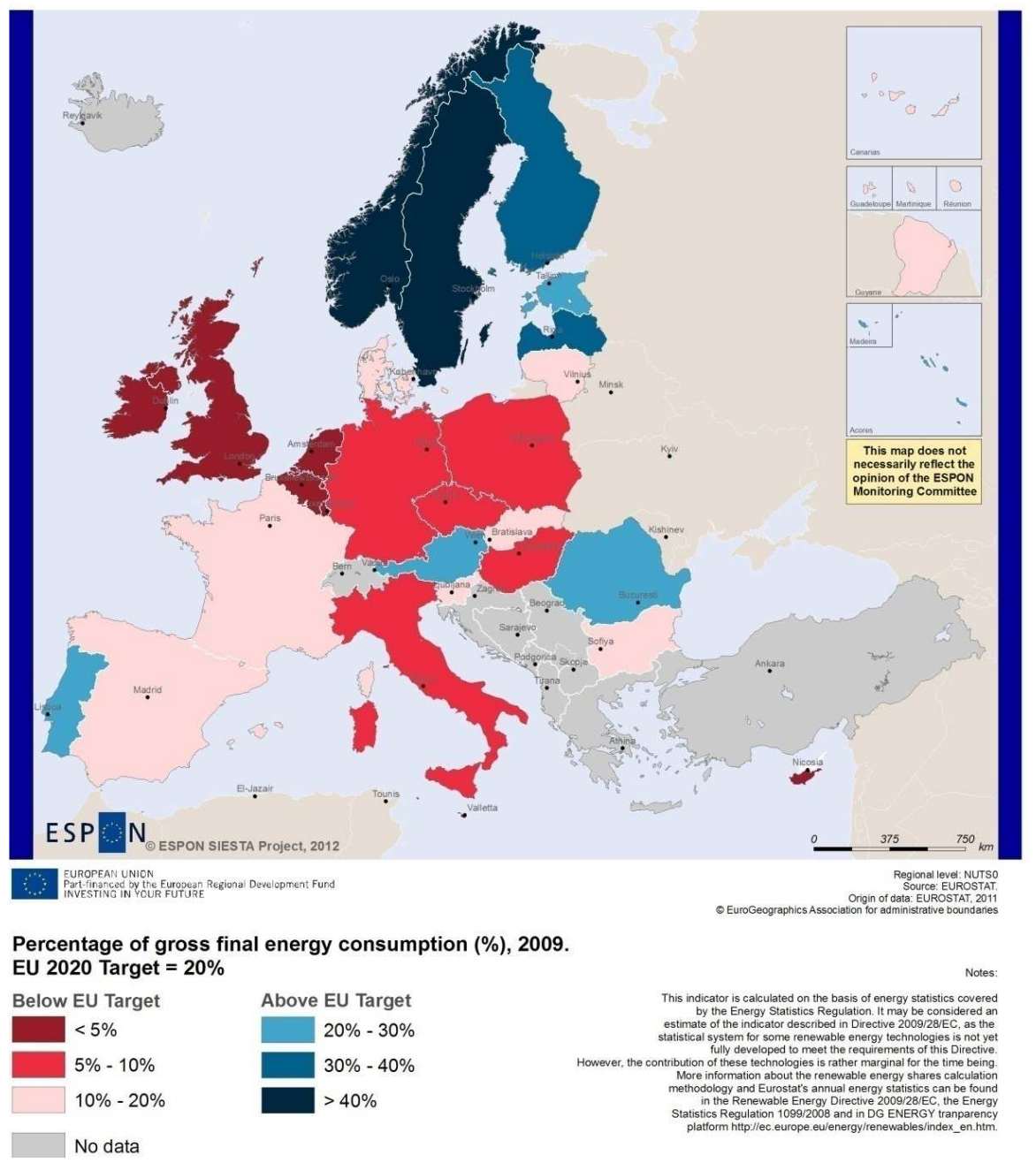

Map 4. Share of renewable energy in gross final energy consumption represented as a percentage (2009).

Scandinavian and Baltic countries (except Lithuania) are the most sustainable in terms of share of renewable energy consumption. Three other countries are above the EU target in different parts of the continent (Austria, Portugal and Romania). The remaining countries are under the EU2020S headline target, with extreme situations in island-states (Malta and Cyprus) and in small countries (Luxembourg, the Netherlands, Belgium), as well as in the UK. Not surprisingly, islands are more dependent on imported fuels. In conclusion, renewable energy patterns express heterogeneous geographical endowments (for instance, Scandinavian countries have widely available hydroelectric and geothermic sources of energy), but also depend on the ambitions of their respective policies. It is currently considered feasible for the EU as a whole to achieve the headline target for renewable energies by 2020 (European Commission, 2011d: 4), possibly due to its obligatory nature, which has stimulated member states to establish adequate objectives and realistic strategies.

Another specific energy target established by the EU2020S is the energy intensity of the economy. This is a complex concept. In fact, officials have recognized the need for refining calculations (European Commission, 2011a: 9). At the present time there are still several accounting methods, even though officially one method has been chosen. The complexity involved is confirmed by the fact that the European Commission (2011e: 8-9, and 2011d: 4) has determined that most member states are not approaching this headline target seriously and are not going to comply with it, in large measure (and this is of interest for this indicator) because the calculation methods for establishing national objectives differ or use different base years.

Map 5 uses data from gross domestic energy consumption per unit of GDP, establishing a relationship between energy and the economy. When a territory reduces this indicator, consumption per economic unit is lower, thus improving energy efficiency. Based on current average EU energy efficiency, we have calculated a reduction of $20 \%$ and determined the distance from that headline target for each country. Only three member states have so far achieved the energy intensity proposed for 2020 (Ireland in first position, followed by Denmark and the UK). On the opposite end we find the Eastern European countries which were officially socialist prior to 1989. They are far from the current EU average and from the 2020 objective (from most to least inefficient: Bulgaria, Estonia, Romania, Czech Republic and Slovakia). This can perhaps be mainly explained by the persistence of obsolete heavy industries in these economies. 
Bulgaria, with an equivalence of $671 \mathrm{~kg}$ of oil per 1.000 euros, is seven times less efficient than Ireland (with $93 \mathrm{~kg}$ ), or Denmark (with $94 \mathrm{~kg}$ ). There is no direct relationship between this indicator and greenhouse gas emissions, since there are efficient countries showing high levels of emissions (Germany and the UK), while others show alarming levels of both indicators (especially the Eastern European countries). Furthermore, energy efficiency shows no relationship with renewable energies.

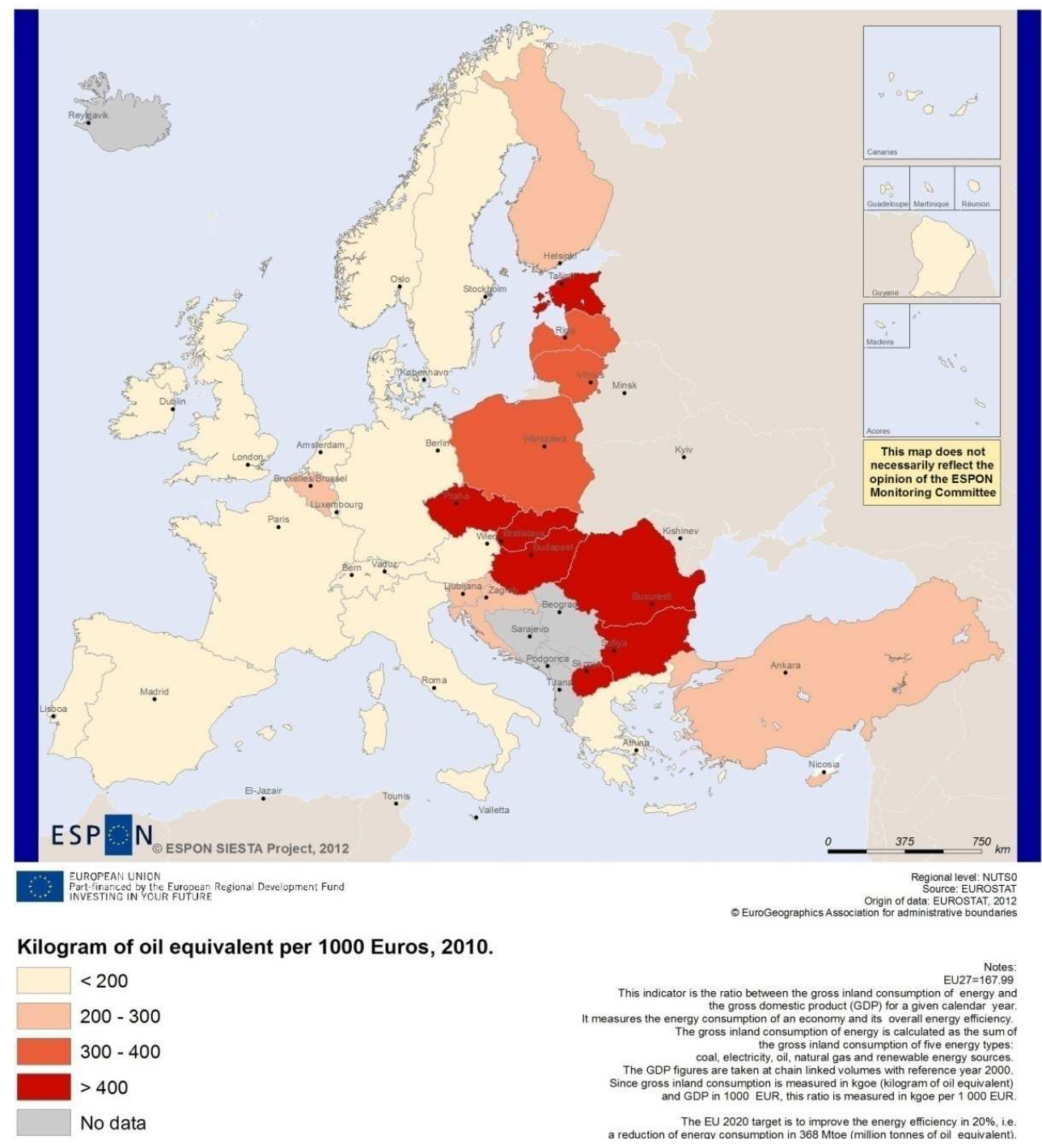

Map 5. Energy intensity of the economy represented as gross inland consumption of energy divided by GDP (2010).

The third 20/20/20 headline target affects the reduction of greenhouse gas emissions in relation with 1990 (Kyoto base year), and with a possible $30 \%$ reduction if adequate conditions were to exist. The so-called "Kyoto greenhouse gas basket" is used. Emissions resulting from land uses and forestry are excluded. Official calculations indicate that a $20 \%$ reduction by 2020 would require a reduction of $21 \%$ based on 2005 levels for sectors under the EU Emissions Trading System, and 10\% for sectors outside this system (European Commission, 2011c: 26), following a complex methodology which has been the subject of serious discussions (Böhringer et al., 2009; Böhringer, Rutherford and Tol, 2009).

Map 6 refers to the above mentioned $10 \%$, using data from the European Commission (2011c) and reworking the classificatory array of the European Environment Agency.
This is the only map of headline targets in this article which shows member state targets rather than European targets, because the former have already been politically agreed upon and are considered official at all levels. ${ }^{6}$ If those objectives are met, it will be possible to reach the Community's stated $10 \%$ reduction, and, as a whole, the $20 \%$ general EU commitment will be reached. Map 6 compares this national objective with the 2005-2010 variation.

\footnotetext{
${ }^{6}$ Annex II to «Decision No 406/2009/CE of the European Parliament and of the Council of 23 April 2009 on the effort of Member States to reduce their greenhouse gas emissions to meet the Community's greenhouse gas emission reduction commitments up to 2020». Official Journal of the EU, June 5, 2009, pp. 0136-0148. This policy, known as «Effort Sharing Decision», can be followed at: $<$ http://ec.europa.eu/clima/policies/effort/>. [Accessed: December 4, 2013].
} 


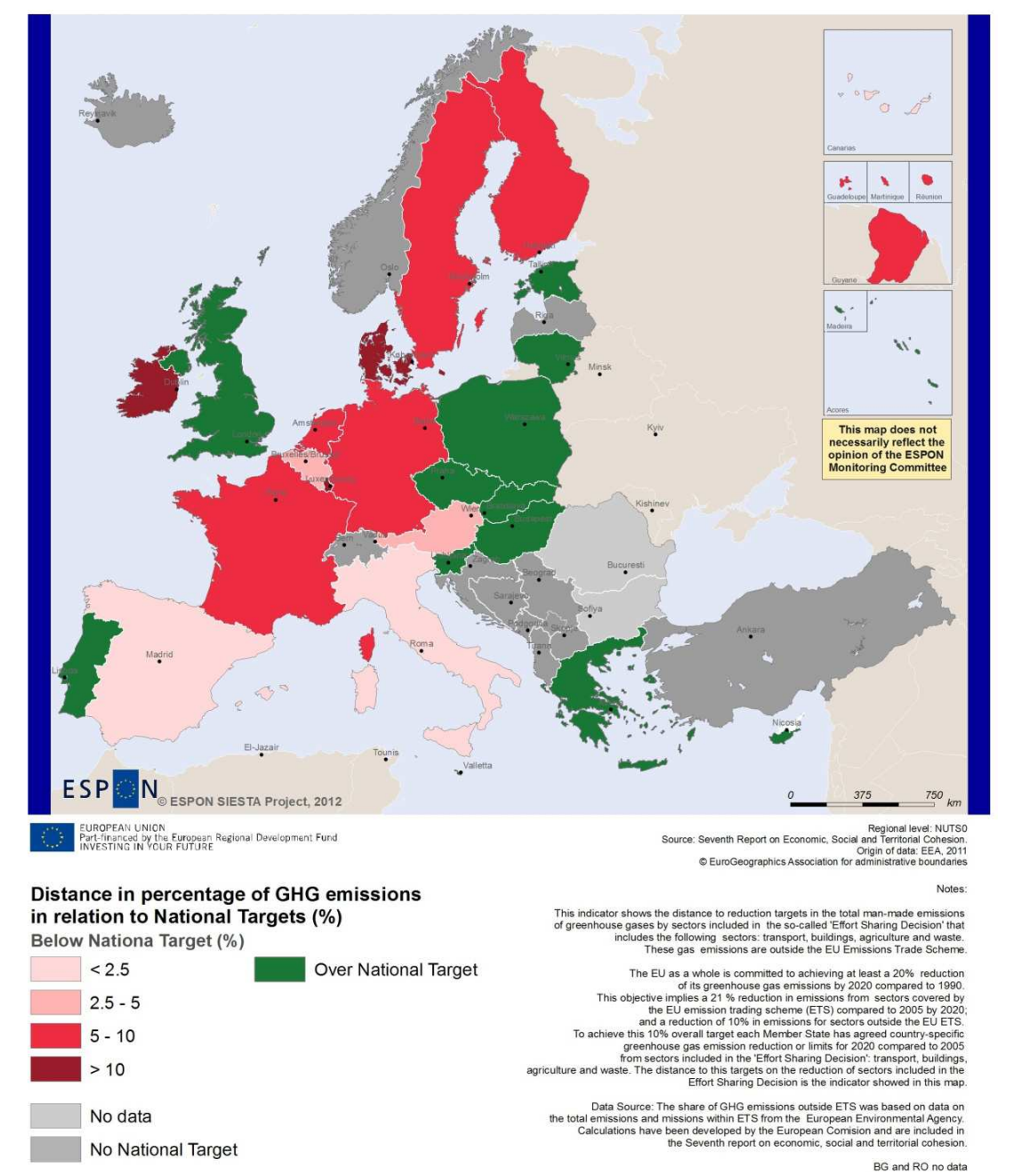

Map 6. Change in greenhouse gas emissions represented as distance to the 2020 national targets (2005-2009).

Countries shown in green on Map 6 are those which have already reached their objective. In these cases, two situations may occur: (i) member states which have set themselves a reduction of greenhouse gas emissions for 2020 and have already reached this reduction (particularly the UK, but also Greece and Cyprus); (ii) countries which have been allowed to increase emissions (in the "Effort Sharing Decision" some countries are allowed an increase), but from 2005 to 2010 have increased them less than allowed (Malta, Poland), or even show a reduction (Hungary, Slovakia, etc.). Countries shown in different tones of red must reduce their emissions and have not yet reached their national objective. Some of these countries, however, are quite near to doing so (Italy, Spain, etc.). The countries that are furthest from their objective are Ireland, Luxembourg and Denmark, since they must still reduce ten percentage points.

Being that the greenhouse gas emissions objective is politically very sensitive and has been established by means of high level political agreements and multilateral institutional decisions - binding for member states - the achievement of this headline target seems feasible, as numerous European Commission reports have been indicating (2011e: 15, y 2011d: 4, 26). Furthermore, the reduction in economic activity due to the crisis will contribute to reaching and even exceeding the established objectives. The current crisis can be interpreted as an opportunity for establishing a more "sustainable" economy, as defined by the EU2020S. It was foreseen that the implementation of the commitment to reduce emissions would bring about a loss in well-being and even an economic contraction (Böhringer et al., 2009; Böhringer, Rutherford and Tol, 2009). In this new scenario in which growth and well-being are both suffering a downturn, emissions are being reduced but are not the cause; instead, they are one of the consequences.

\section{Inclusive Growth}

The third aim of the EU2020S deals with employment creation, skills and labor market reform and, furthermore, the reduction of poverty and social exclusion. The basic intention is to increase employment rates and job quality, especially for those groups in difficulty (women, youth, migrants, older workers, etc.), thus helping maintain social 
cohesion. The emphasis on these issues is based on an economic verification: Europe needs to make full use of its labor potential to face the challenges of an aging population and rising global competition. In relation to poverty, the prediction is that the number of poor will increase because of the crisis, with a particular factor of risk associated with unemployment. In fact, structural unemployment is seen as a problem that must be reduced to avoid higher levels of poverty.
The commitment to the headline target of an employment rate of $75 \%$ for the $20-64$ year-old age group by 2020 is ambitious, but it is critical for the sustainability of Europe's social model, welfare, growth and public finances (Map 7). Taking into account that in 2011 the EU scored $68.6 \%$, the achievement of this target will not be an easy task, especially in the current contraction period, where destruction of employment is severe in several countries and unemployment is increasingly becoming a matter of worry.

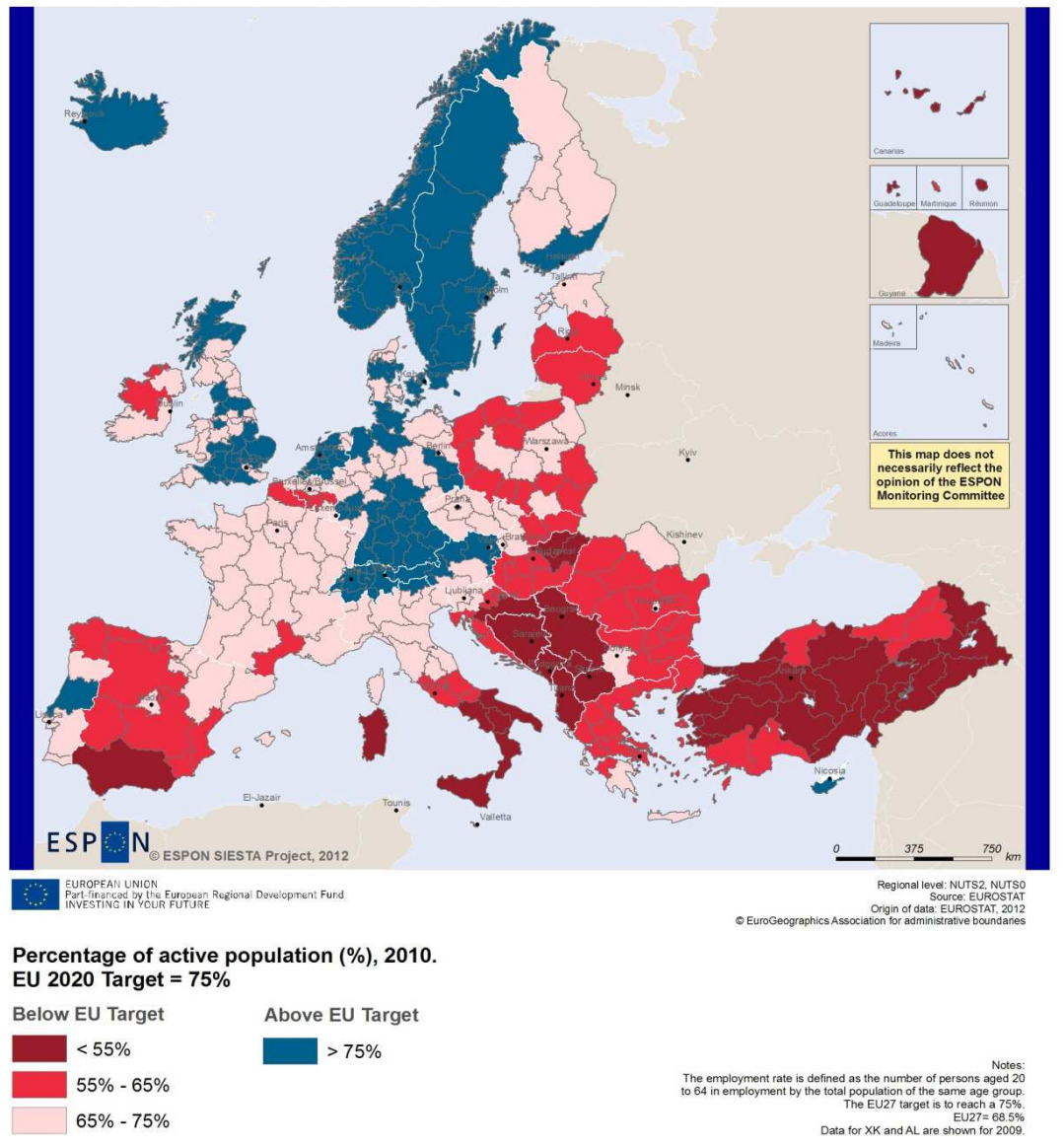

Map 7. Employment rate as a percentage of active population aged 20 to 64 (2010).

The EU's general data is disaggregated into an enormous territorial variation. To start with, numerous regions exceed the threshold, although this is the case of only seven of the twenty-seven member states, as can be seen on the map. Northern Europe is the macroregion with the greatest percentage of regions with high or very high levels of employment, with Sweden being the only country in which all regions are above the European objective. The UK, Germany, Austria and the Netherlands show numerous territorial units with a ratio above $75 \%$.

In Mediterranean Europe and the Eastern countries a number of regions are very far from achieving this headline target. In Eastern Europe some of the regions with the worst results have undergone a process of industrial restructuring, but others territories which underwent the same process as the former Eastern Bloc countries (or countries such as the UK or France) have overcome this challenge and are currently near to achieving or surpassing the $75 \%$ objective.
This is the reason why future research projects should delve deeper into the reasons for the uneven results of production and industrial reconversion policies within the EU. The extremes of this scale are surprising: the Åland Islands in Finland are at $84 \%$, while the region of Campania in Italy is below $44 \%$; thus, the worst positioned region has a level of employed population almost half of that of the best positioned region, which is doubtlessly a result of the low level of female insertion in the workforce. This factor explains much of the less favorable data found in Southern Europe.

Spain and Italy show an enormous interior disparity: their northern regions are very close to the Community average and some are even near the $75 \%$ objective; however, the further south we go, the worse the rates become, with the minimum found in Campania, as previously mentioned. In Spain, the worst rates are those of Ceuta (50\%) and Andalusia (52.6\%). In general, it could be argued that the member state scale is 
important for explaining the patterns of Map 7, since within each member state the different regions show similar scores. Nevertheless, the cases of Italy and Spain are particularly perplexing due to their evident internal variation which, geographically, is found latitudinally.

In relation to poverty, as previously mentioned, the headline target is the reduction of twenty million poor by 2020 . This is the only indicator which is not a percentage, thus complicating its mapping. In relation to the indicator used by the EU, its inextricable calculation should be noted, since it has been criticized by such authors as Nolan and Whelan (2010). For this article we can only use as our source the data offered by Eurostat by means of a classificatory array which is already closed. The data are offered at different scales depending on the countries, and there are several member states for which no disaggregation can be obtained. The classificatory array is shown as percentage of population at-risk-of-poverty in each region, but the indicator is a total volume resulting from the calculation of the number of poor in each region. If the reduction of twenty million poor implies a reduction of $17 \%$ on an EU scale, it is assumed that all territories must reduce this percentage homogeneously, and the "desired level of population at risk of poverty" for 2020 is thus obtained. The difference between the current population and the "desired" in 2020 for each territorial unit is represented in Map 8.

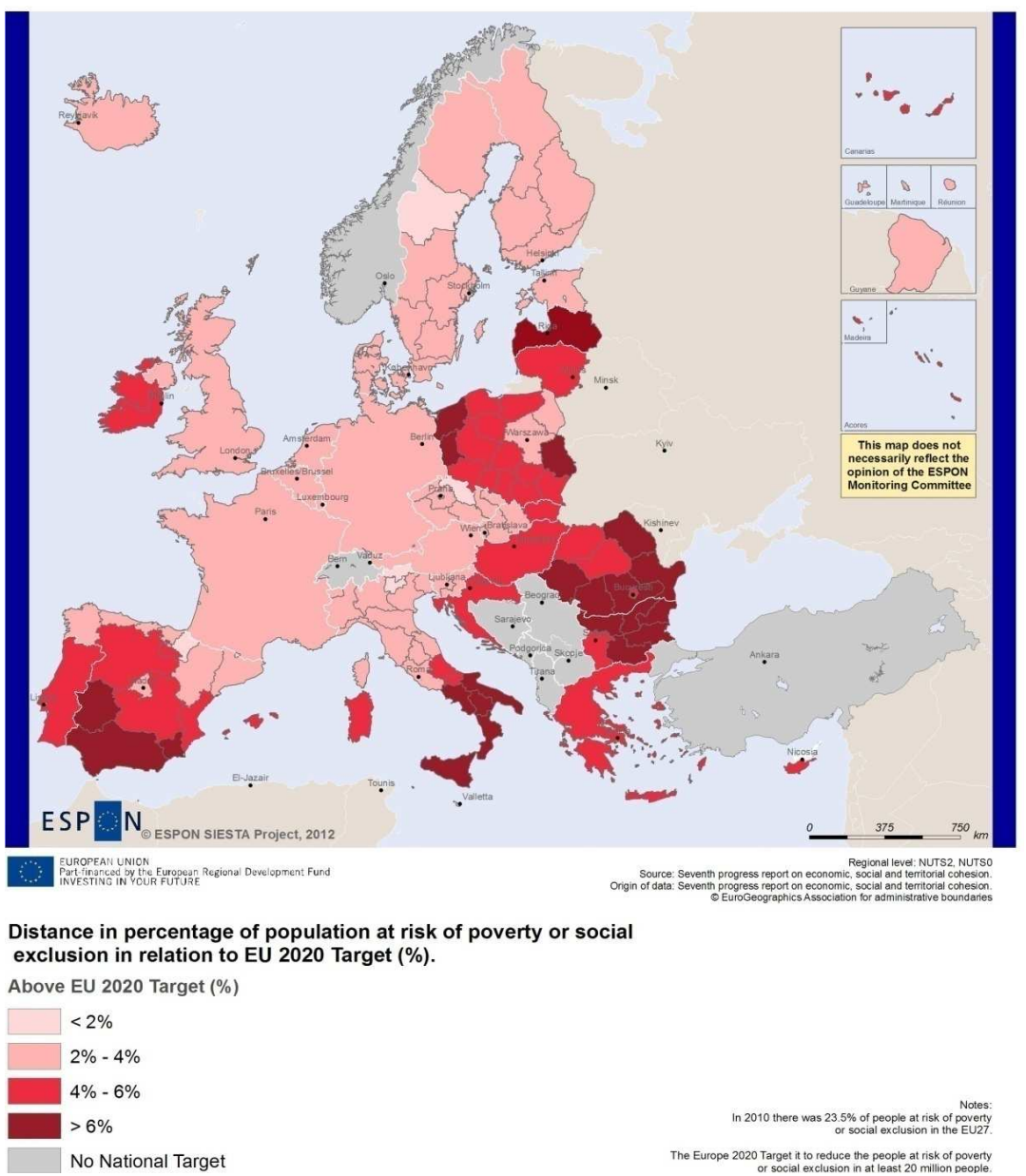

Map 8. Regional/national population at-risk-of-poverty or social exclusion represented as distance to the EU2020 target (2010).

To the extent that the current situation is compared with the one established as the objective for 2020, the regions with a greater percentage of people at-risk-of-poverty are obviously found at a greater distance from the goal established for the end of the decade. Thus, many regions of Bulgaria and Romania are in a worse position, but in the same situation as Campania or Sicily (Italy), and Ceuta or Extremadura (Spain). In Italy and Spain we also find regions such as Navarra (in third position with less distance to the European objective) or Trentino-Alto Adige/Südtirol (in fourth position). These regions will require little effort to reach the desired target because the current percentage of population at-risk-of-poverty is already comparatively low. In any case, the territorial variation of this indicator is evident and tends to show how Europe's southerly most regions, together with Bulgaria and Romania, are straggling. In Poland and Latvia we also see regions in a particularly dire situation.

\section{The Composite Index}

In order to assess the overall fulfillment of the EU2020S, a composite index has been developed. This composite index measures the distance of regions from eight EU2020S headline targets. A region would score 100 if it had reached all eight targets, while a region furthest away from all eight targets would score 0 . This methodology was inspired by the 
Lisbon index of the $5^{\text {th }}$ Cohesion Report (European Commission, 2010c: 195-196). The targets are obviously those officially set by the European Commission, given that the nationally set targets are highly inconsistent and not all member states are currently providing national targets.
This composite index is represented on Map 9 for 2009-2010, taking into account that three headlines are only available at the member state level (the "20/20/20"), and a fourth one is available with different scales depending on the country (people at-risk-of-poverty or social exclusion).

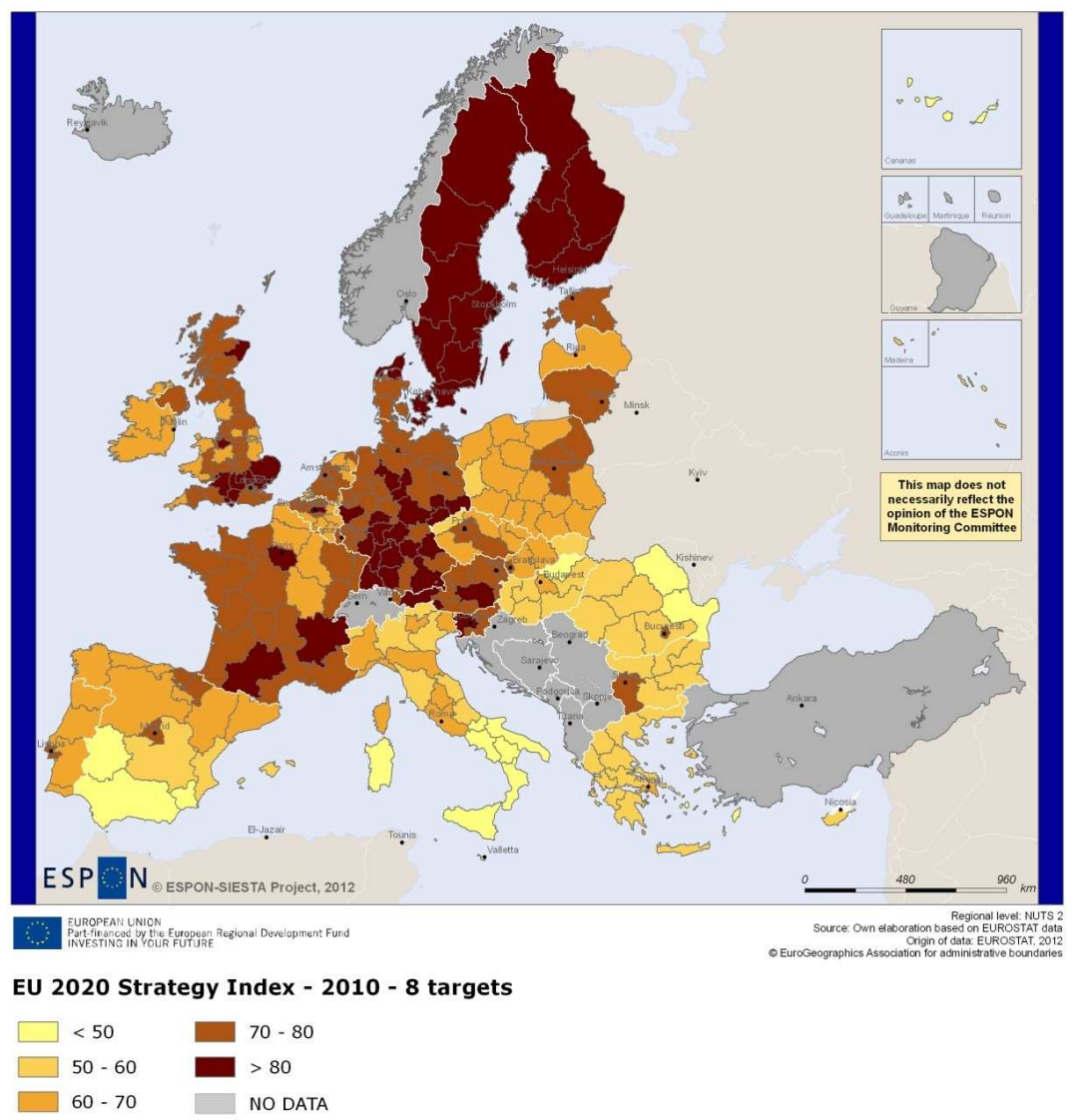

Map 9. EU2020S aggregate index (2009-2010).

The index is strongly stressed due to the fact that the EU2020S covers a wide range of topics, a range that has been specifically translated into headline targets. In other words, although the regions scoring higher are reaching or almost reaching the eight targets, all the regions in intermediate positions are in very different situations which vary from case to case and imply different reasons for their position in the ranking, and must therefore be managed through diverse policies and be the object of different recommendations. In fact, two regions with the same scores might account for very different realities. The EU2020S, however, is plural in its very nature, and the objective of the composite index is to reflect its general fulfillment at the regional scale, rather than scoring each of its constitutive topics as has been done across the SIESTA Project in each of the different thematic sections.

Map 9 shows that the top positions in the achievement of the regional EU2020S composite index for 2009-2010 are held by the Scandinavian regions, plus Southern Germany, several French regions and Southern England (basically, North of London but also Hampshire). In Sweden, five regions register an index above $90 \%$. This pattern broadly coincides with two of the three corridors repeatedly identified in relation to $R \& D$ and innovation performance (Bundesamt für Bauwesen und Raumordnung, 2006: 30): Midi-Pyrénées (France) to Bavaria (Southern Germany), and Denmark to Finland. Some capital regions (Île-de-France, Greater London, Berlin, Brussels, Copenhagen, Ljubljana) also score particularly high and are included in the group of regions above $80 \%$. The third corridor which is usually defined (between Austria and London) is less clear, because there are regions scoring relatively low in relation to their neighboring geographical units (e.g., Wallonie in Belgium, and Picardie and Nord-Pas-de-Calais in France).

In contrast, in the bottom positions we find Eastern Romania, Észak-Magyarország (Hungary), Southern Italy and Southern Spain, plus Spain's outermost regions; some of the regions lagging behind have scores of less than $40 \%$. In Spain and Romania, there are dramatic imbalances between regions, with high figures (Madrid, the Basque Country and Navarra in Spain; Bucharest-Ilfov in Romania) in countries dominated by low figures. 


\section{Conclusions}

Our main conclusion is that the achievement of smart, sustainable and inclusive growth as envisaged by the EU2020S (European Commission, 2010a) is far from near, not only in terms of time but also in territorial terms. According to Çolak and Ege (2013), it is simply "too far to reach," both for the EU as a whole and for each region, as shown in the previous section. We believe there is much evidence showing the frailty of the official EU growth strategy for the 2010-2020 period. We think this frailty has nothing to do with the three priorities identified by the EU2020S - which are commendable and probably suitable channels for strengthening the EU's economy in times of crisis and, likewise, for increasing and challenging global competition - but, instead, with the design of this tool. Indeed, the fiasco of the Lisbon Strategy has shown the need to develop a distinct type of document for the present decade, and to not reiterate its structural errors. This scenario, however, has occurred. Lundvall and Lorenz (2011) and Treidler (2011) had already anticipated that the EU2020S was doomed to failure because it largely suffered from the frailties of the Lisbon Strategy, starting from its non-binding nature. Farinós (2008), upon analyzing the Lisbon Strategy, also pointed to the absence of governance in its implementation as being a significant defect, something which undoubtedly repeats itself in the EU2020S.

On the other hand, we believe, as Erixon (2010) has argued, that focusing on competences that are not the responsibilities of the Commission (education, poverty, etc.) detract legitimacy from the EU2020S. This also leads to member states having to take charge of their development, something which - through national objectives which systematically "downgrade" the European headline targets - enormously biases the process. In this sense we share the views of Colomb and Santinha (2012) in that the "planning agenda" of the EU (EU2020S, Territorial Agenda, etc.) is weak in comparison to macro-economy policy, this being clearly decisive. What is more, both contradict each other constantly. In fact, at no time can it be said that investments in education or the struggle against poverty are a real priority for EU institutions - not even for the member states in general - but rather for the macro-economy, with persistent objectives such as austerity. In short, a stronger link to the EU2020S could be a suitable way to achieve the smart, sustainable and inclusive growth which has been envisaged for a decade currently immersed in an acute crisis.

\section{References}

[1] Anton, S. \& Gonzàlez Reverté, F. (Coordinators) (2005). Planificación territorial del turismo. Barcelona, Universitat Oberta de Catalunya.

[2] Blewitt, J. (2009). Understanding Sustainable Development. London, Earthscan.

[3] Böhme, K. et al. (2011). How to Strengthen the Territorial
Dimension of 'Europe 2020' and the EU Cohesion Policy. Warsaw, Ministry of Regional Development.

[4] Böhringher, C. et al. (2009). EU Climate Policy up to 2020: an Economic Impact Assessment. Energy Economics 31, pp. 295-S305.

[5] Bundesamt Für Bauwesen Und Raumordnung (dir.) (2006). ESPON Atlas. Mapping the Structure of the European Territory. Bonn: Bundesamt für Bauwesen und Raumordnung.

[6] Butković, H. \& Samardžija, V. (2010). From the Lisbon Strategy to Europe 2020 - An Introduction. In: Samardžija, V. \& Butković, H. (Editors). From the Lisbon Strategy to Europe 2020. Zagreb, Institute for International Relations, pp. 3-30.

[7] Capello, R. (coord.) (2012): KIT (Knowledge, Innovation, Territory). Applied Research 2013/1/13. Final Report. Version 13/11/2012. Executive Summary. ESPON/ Politecnico di Milano, Luxembourg/Milan, 18 pp.

[8] Colomb, C. \& Santinha, G. (2012). European Union Competition Policy and the European Territorial Cohesion Agenda: An Impossible Reconciliation? State Aid Rules and Public Service Liberalization through the European Spatial Planning Lens. European Planning Studies. [Forthcoming]

[9] Çolak, M. S. \& Ege, A. (2013). An Assessment of EU 2020 Strategy: Too Far to Reach? Social Indicators Research 110(2), pp. 659-680.

[10] Erixon, F. (2010). The Europe 2020 Strategy: Time for Europe to Think Again. European View 9(1), pp. 29-37.

[11] ESPON (2013). ESPON Atlas, June 2013. Territorial Dimensions of the Europe 2020 Strategy. Luxembourg, ESPON.

[12] European Commission (2010a). Europe 2020. A strategy for smart, sustainable and inclusive growth. Brussels, 3.3.2010. [COM(2010) 2020 final]

[13] European Commission (2010b). Regional Policy contributing to smart growth in Europe 2020. Brussels, 26.1.2011. [COM(2010) 553 final]

[14] European Commission (2010c). Investing in Europe's future. Fifth report on economic, social and territorial cohesion. Luxembourg, Publications Office of the European Union.

[15] European Commission (2011a). A resource-efficient Europe - Flagship initiative under the Europe 2020 Strategy. Brussels, 26.1.2011. [COM(2011) 21 final]

[16] European Commission (2011b). Regional policy contributing to Sustainable Growth in Europe 2020. Brussels, 26.1.2011. [COM(2011) 17 final]

[17] European Commission (2011c). The Urban and Regional Dimension of Europe 2020. Seventh Progress Report on Economic, Social and Territorial Cohesion. Luxembourg, Publications Office of the European Union.

[18] European Commission (2011d). Annual Growth Survey 2012. Brussels, 23.11.2011 [COM(2011) 815 final. Annex 1]

[19] European Commission (2011e). Annual Growth Survey: advancing the EU's comprehensive response to the crisis. Brussels, 12.1.2011. [COM(2011) 11 final. Annex 1] 
[20] Farinós, J. (2008). Gobernanza territorial para el desarrollo sostenible: estado de la cuestión y agenda. Boletín de la Asociación de Geógrafos Españoles 46, pp. 11-32.

[21] Kotz, D.M. (2009). The Financial and Economic Crisis of 2008: A Systemic Crisis of Neoliberal Capitalism. Review of Radical Political Economics 41, pp. 305-317.

[22] Lois-González, R.C. \& Paül, V. (Ed.) (2013). European Regions in the Strategy to Emerge from the Crisis: the Territorial Dimension of the 'Europe 2020'. Santiago de Compostela, Universidade de Santiago de Compostela Publicacións.

[23] Lundvall, B. \& Lorenz, E. (2011). From the Lisbon Strategy to Europe 2020. In: Morel, N., Palier, B. \& Palme, J. (Editors) Towards a Social Investment Welfare State?: Ideas, Policies and Challenges. Bristol, Policy Press, pp. 333-351.

[24] Moltó, M. (2012). A nova gobernanza económica na UE: avances e carencias. Revista Galega de Economía 21, pp. $37-66$.
[25] Nolan, B., \& C. T. Whealan (2011). The EU 2020 Poverty Target. UCD Geary Institute Discussion Paper Series, Dublín, $37 \mathrm{pp}$.

[26] Naredo, J.M. (2007). Crecimiento insostenible, desarrollo sostenible. In: Romero, J. (Coordinator). Geografia humana. Procesos, riesgos e incertidumbres en un mundo globalizado. Barcelona, Ariel, pp. 421-476.

[27] Treidler, O. (2011). Evaluating the Lisbon Strategy. Würzburg, Bayerische Julius-Maximilians-Universität Würzburg.

[28] Warleigh-Lack, A. (2010). Greening the European Union for legitimacy? A cautionary reading of Europe 2020. Innovation: The European Journal of Social Science Research 23(4), pp. 297-311.

[29] Zoido, F. et al. (coords.) (2013). Diccionario de Urbanismo. Geografia urbana y ordenación del territorio. Madrid, Cátedra. 